\title{
Exploring EFL Learners' Perceptions about Journal Writing: Voices from the Saudi Context
}

\author{
Dr. Hanady Abdulaziz Alfalig \\ English Department, College of Sciences and Arts, King Abdulaziz University, Rabigh, Saudi \\ Arabia \\ P.O. Box 344, Rabigh 21911 \\ E-mail: Halfalig@kau.edu.sa \\ Dr. Baraa Adel Rajab (Corresponding author) \\ English Language Institute, King Abdulaziz University, Jeddah, Saudi Arabia \\ P.O. Box 80200, Jeddah 21589 \\ E-mail: Brajab@kau.edu.sa
}

Received: July 2, 2019 Accepted: August 30, 2019 Published: September 2, 2019

doi:10.5296/ijele.v7i2.15386 URL: https://doi.org/10.5296/ijele.v7i2.15386

\begin{abstract}
This small-scale qualitative study aims to explore the Saudi EFL learners' perceptions and experiences about their journal writing practice. The study adopts an interpretive approach to understand the multiple realities and subjective experiences of twenty-two female students in the Saudi context. Suiting its purpose, this study utilizes a qualitative data collection tool, which are semi-structured interviews to elicit and gather EFL learners' views about their writing skills and journal writing activity. The interviews were manually transcribed and inductively analyzed aiming to answer three research questions. The iterative process of data analysis led to the emergence of five major themes which are: a) The Trend of Writing a Journal in the Saudi Context; b) The Significance of Writing a Journal in the Saudi Context; c) The Impact of Writing a Journal on EFL Learners' Writing Skills; d) The Challenge of Writing a Journal in the EFL Context; and e) The Future of Writing a Journal in the Saudi EFL Context. In the light of the findings, recommendations and suggestions are put forward to make journal writing an integral part of the EFL curriculum in the Saudi EFL context.
\end{abstract}

Keyword: A qualitative study, EFL students, Saudi EFL context, Writing skill, Writing a journal 


\section{Introduction}

Writing is one of the four basic skills of learning a foreign or second language. It is widely acknowledged that writing is the last language skill to be learned and mastered both by native speakers of the language and foreign/second language learners irrespective of the contexts (Hamp \& Heasly, 2006). For most of the EFL students around the world, English writing is a challenging phenomenon and learners face numerous difficulties overcoming their weaknesses while mastering this skill in classroom environment. Acknowledging its vital role in the process of learning a foreign language, Glazier (1994) states that "It is very important to be able to write in English in college, and it will be probably an asset in the career" (p. 3). Similarly, Nunan (1999) believes that the most difficult thing in a language is to be able to produce a coherent, fluent, and extended piece of writing since the reader is required to comprehend and understand without asking for any clarification of what has been written.

Owing to its intricate nature, EFL teachers often face challenges to motivate learners in improving their writing skills. Since writing is not an enjoyable activity as compared to other language skills, motivating learners is not an adequate strategy and teachers have to think out of the box in a bid to enhance their writing skills (Hedge, 1991). As writing tasks are often assessed in class, most of the EFL/ESL learners find it discouraging due to the fact that it will come under the scrutiny of the classroom teacher who will find errors to be corrected in their writing. Hamp and Heasley (2006) states:

Few people write spontaneously and feel comfortable with a formal writing task intended for the eyes of someone else. When the "someone else" is the teacher, whose eyes may be critical, and who indeed may assign an individual assessment to the written product, most people feel uncomfortable" (p. 2).

Research shows that second/foreign language learners encounter various problems when attempting to write in English. They often find themselves stuck with the ideas when it comes to writing tasks since they are supposed to write what is assigned to them by their teacher; rather than writing about their own ideas which bear some relevance to them. According to Byrne (1991), "Being at a loss for ideas is a familiar experience to most of us when we are obliged to write" (p.5). In a similar way, Tho (2000) states that "Non-native writers may not have enough ideas to write down or, even worse, they have nothing to say" (p. 36). It shows that learners' own idea or the topics that learners can relate to are of paramount importance that can trigger learners' interest in the process of EFL writing.

Adding to the problems students encounter in an EFL writing class, time constraints are also highlighted by the researchers as the learners' writing effectiveness is hindered by the time pressure. Students are compelled to finish their writing tasks within a certain period of time because of which many students fail to complete their tasks, which results in their de-motivation. On time constraints, Weir (1990) states that time pressure has always been a problem for students as the writing process is lengthier and needs time and several tasks before completing and producing a final outcome. In this regard, Chanderasegaran (2002) indicates, "A problem to be expected in the writing classroom is that some students take much longer than others to write the required parts of the essay. Many never finish their 
writing in class" (p. 14).

Since writing is considered an important skill, Saudi EFL learners often need more time and effort to improve their writing skills. The public universities across the Kingdom and their Preparatory Year Programme (PYP) have put a great emphasis on developing the EFL learners' writing skills. Various strategies, top-notch techniques, and up-to-date methodologies have been added to the teaching repertoire in order to bring up the Saudi EFL learners' writing skills to an acceptable level in the market. In this respect, a newly introduced technique of writing a journal as part of free writing has been introduced in different universities; however, it has not been granted an indispensable place in curriculums and syllabi. As its significance is widely acknowledged, this study will explore the perceptions of Saudi EFL learners about their experience of writing journals and find out what difficulties they encounter in a typical journal writing activity. This qualitative and exploratory research aims to answer the following three research questions:

1. To what extent do EFL learners consider journal writing an important tool for improving their writing skills?

2. What are the EFL learners' perceptions of their experience of journal writing in an EFL classroom?

3. What are the factors that hinder the process of journal writing in the Saudi EFL context?

\section{Literature Review}

\subsection{The Nature of Journal Writing}

It is widely acknowledged that academic achievement cannot be measured without improved writing skills as students always require to writing assignments, papers, articles, thesis, and dissertations in their academic endeavors. Parallel to the students' academic writing activity inside the classroom, writing outside the classroom is also a useful tool for improving the writing skill (Chanderasegaran, 2002). One of the best ways to practice writing outside the classroom is to keep journals, "which are the notebooks in which the writers record their ideas, opinions, and descriptions about their daily lives. Keeping or writing a journal helps the writer to develop his/her creativity" (Spaventa, 2000, p. 168). Moreover, writing a journal allows students to write freely without thinking much about their grades as it is an opportunity for them to write on topics of their choice. As a result, their writing skill improves and they grow into confidence. Hamp and Heasley (2006):

The most obvious way you can help yourself become a good writer is by writing. We strongly suggest that in addition to completing the tasks, you also keep your own personal journal. Buy yourself a notebook, and try to write down some ideas every day, in English, about anything that interests you (...). You will surprise yourself by producing pages and pages of writing. (p. 5)

It is an undeniable fact that giving the students a chance to write about the relevant things is 
an "an active learning technique" (Chickering \& Gamson, 1987, p. 5). Keeping the journals helps the learners to keep a record of their personal or life activities. The importance of personal or life writing has been valued by many scholars. Moreover, journal writing is considered an enjoyable experience by most of the students keeping in view the primary aim of keeping a journal, which is "to encourage students to become involved and interested in writing" (White \& Arndt, 1991, p. 63) without thinking much about errors and time pressure (Spaventa, 2000, p.168). To add to the benefits that "journal writing provides students with good opportunities to improve their writing skills individually and good chances to record their thoughts and feelings" (Ngoh, 2002, p. 27). In a similar way, Spaventa (2000) observes:

There are a lot of perks of keeping a journal. In addition to the informal conversation that takes place in it between you and yourself and you and your instructor: when you have finished the course, you will have a record of what you read, what you experienced and what you thought about during that time. (p. 168)

There is a consensus among the researchers that journals do not just help students write better but they also help the students with their motivation and self-esteem. When used as a tool for response to literature, which is either dictated to the students or read by the students themselves, journals prove to be a valuable medium for developing critical thinking and reading comprehension. Some students could even notice an increase in their analytical approach to learning, as a result of which, their performance in other classes improved as well (Simpson, 1986).

A lot of work has been done on the effectiveness and usefulness of journal writing as a learning resource in the ESL/EFL classroom. Dotson (2001) in journal writing pathfinder gives information of the ways to access resources in journal writing. The author presented resources focusing on different journal types and benefits, the logistics to implement journal writing, and the role of the teacher in this process as both observer and participant. According to Pierson (2004) while discussing on the Perspective of Journal Writing for ESL/EFL Classroom, defined the dialogue journal based on its definition, goals and procedures, benefits and limitations and he found out that the learners were eager to start writing, once they understood the overall writing process.

Ediger (2001) has identified the following advantages of journal writing:

(1) Each student has ownership of his/her written script. The student then is the chooser as to what to write about.

(2) Students may feel that writing is individualized in that each may select, organize, and sequence content to write about.

(3) Writing is personalized in that the learner writes about feelings, subject matter, attitudes, and values; about what is prized in the social studies curriculum.

(4) Learners may choose to write in an intrapersonal or interpersonal manner. 
(5) Self-evaluation of the journal is possible as well as the use of qualified adults to assess journal entries

Ediger (2001) has identified the following advantages of journal writing:

(1) Each student has ownership of his/her written script. The student then is the chooser as to what to write about.

(2) Students may feel that writing is individualized in that each may select, organize, and sequence content to write about.

(3) Writing is personalized in that the learner writes about feelings, subject matter, attitudes, and values; about what is prized in the social studies curriculum.

(4) Learners may choose to write in an intrapersonal or interpersonal manner.

(5) Self-evaluation of the journal is possible as well as the use of qualified adults to assess journal entries

In another study, Ediger (2001) has identified the following advantages of journal writing. For example, students can feel the ownership of the script and they can have a choice about the topic. as writing is a personalized effort, learners can write about their feelings, attitudes, subject matter and values which they can select and organize themselves. Choosing their intrapersonal or interpersonal style, learners can evaluate and assess their writing in a much better manner (Ediger, 2001).

Owing to that personalized effect, journal writing is not only beneficial to learners but it is helpful to teachers as well as it not only improves the relationship between a teacher and the learner but also gives a glimpse of what is going on in the mind of their learners. It has been well defined that journal writing is the process of "thinking aloud" on the paper. To corroborate with the view, one of the students in Mllynarczyk's (1998) class wrote: "it is free writing. I wrote the first sentence and then I continued writing almost without any stops." Another student wrote: "I didn't decide. It came by itself" (p. 45). Mllynarczyk explains: "by writing freely, without focusing on form or organization, these writers had a chance to experiment with language and follow their own ideas" (p. 45).

Motivation can play a key role in not only helping the learners write about their own interests and the subjects relevant to their lives but also in helping them to go beyond personal subjects and focus on much bigger issues in their writings. As shown by many studies, language learning is a complex process and in this whole process the learners' expectations, beliefs, and values play an important role. Relying only on the linguistic input and output of the classroom will not help, but learners' selves need to be tapped and heard what they think about. One of the best way to learn about their perceptions would be to ask them to regularly write about their feelings in a journal. 


\subsection{Journal Writing and its Impact on Students 'Learning}

Journal writing is a means of students' engagement and classroom interaction. It is a learning process that encourages students to reflect, brainstorm, think about the content, discuss and develop a rapport with classroom teacher (Surbeck, 1994). It also allows the teacher to read and respond to the students' entries with comments on their written work. Although the work is mainly done outside classroom, the whole process involves learners and teachers sharing their views in a very comfortable environment.

Research indicates that journal writing is not merely a learning tool for the students, it assists teachers as well. Apps (1991) considers it a learning and teaching tool for adults that helps in brainstorming of new ideas. In Haglund's (1998) view, journal writing is a way of connecting learners' school lives to events in history and instances in the real world. More importantly, it creates a trusting relationship between the students and teachers as they share their true stories.

Studies show that reflective journal writing enhances learners' information synthesis skills (Hettich, 1976). It enables learners to ask questions, make connections, admit confusion and develop their ideas in an organized manner (Good, 1999). Similarly, Cisero (2006) states that journal writing may not prepare students for exams, but it certainly helps in enhancing their reading and content engagement skills. Cisero (2006) also believes that students with low motivation and underachievement can benefit from journal writing. However, Heron (2003) suggests that it should not be pre-planned or repetitive in nature.

Hashemi and Amerian (2017) conducted a quantitative study in the Iranian context to determine the impact of journal writing on EFL learners' grammar acquisition. The findings suggest that EFL learners who took part in the experiment of journal writing showed significant improvement in grammar learning compared to the controlled group. Interestingly, the learners were not given any instruction on grammar who learned or improved grammar aspects by themselves through reflecting on and correcting their mistakes. Like other researchers, Hashemi and Amerian (2017) also concluded that EFL learners can benefit a great deal from writing a journal since free writing ease the process of thinking and organizing ideas. Therefore, they suggest that EFL teachers include such activities in their teaching repertoire.

\subsection{Journal Writing in the Saudi EFL Context}

Bearing in mind the importance of writing skill, educational institutions around the world have made it a compulsory component for students at the undergraduate and graduate levels. In the context of Saudi Arabia, students in preparatory years take an 18-hours language course per week for one academic year. The focus of the course is mainly to develop the EFL learners' English proficiency and upgrade their academic skills to compete in local and global markets. Nevertheless, in classrooms, writing tasks mainly focus on the improvement of students' writing skill and their overall English proficiency irrespective of their appropriateness and effectiveness. As part of a teaching and learning tool, journal writing is a fairly new phenomenon in this context, which may be an effective tool to develop EFL learners' writing skills outside the classroom. In connection to this tool, this exploratory study 
aims to understand the Saudi learners' views and experiences about this language learning tool and its effectiveness.

Despite its numerous advantages for learners and teachers, journal writing seems to be a novel concept in the Saudi EFL context. The PYP contains the writing component and there are writing centers in some of the universities in the Kingdom, however, this notion has not been fully implemented in the Saudi educational institutions. It may have been applied in some settings, but there appears to be no published research on this topic. Since the topic is of paramount importance for language learners to improve their writing skills, this research will contribute to the literature by enabling the EFL learners to share their experiences and perceptions about journal writing. Indeed, EFL learners and teachers in other EFL contexts can take the findings as a guideline for their endeavors in learning about and teaching the techniques of journal writing.

\section{The Study Design}

\subsection{The Context of the Study}

As English has acquired the status of a global language, it has been made a mandatory foreign language in Saudi educational institutions across the Kingdom. As a language policy, Saudi schools and universities have implemented English as a foreign language and a medium of instructions for Arts and Science students at secondary and tertiary levels. To meet the policy criteria, PYP has been established in all public and private universities that meet the language learning needs of thousands of Saudi EFL learners. In the context of the current research, the English Language Institute (ELI) offers an intensive EFL program to more than 6000 students. The course is delivered by more than 100 language teachers with various L1 backgrounds. The focus of the PYP is to develop the EFL learners' integrated language skills.

The PYP runs over four modules over the period of 10 months. Following a weekly pacing guide, teachers apply a level-based learners' textbook and workbook for a module of 7 weeks. Students take a placement test prior to their distribution into appropriate levels. The placement test is designed following the Common European Framework (CEF) that facilitates the process of placing students in suitable levels, such as Beginner (A0) to Pre-Intermediate (B1). EFL students are promoted to the next level once they complete a module successfully.

\subsection{Methodology}

This exploratory study is situated in the interpretive paradigm to explore the EFL learners' perceptions and experiences of journal writing in the EFL context. According to Marshall and Rossmans (1999)," for a study focusing on individual lived experiences, the researcher could argue that one cannot understand human actions without understanding the meaning that participants attribute to these actions, their thoughts, feelings, beliefs, values, and assumptive worlds" (p. 57).

The interpretive approach is suitable for the nature of the current research as it allows us to 
interact with the participants and understand the research phenomenon in-depth. Being classroom teachers, our role has been both as investigators and observers as explained by Borg and Gall (1983) that "by being actively involved in the situation that the researcher is observing, the researcher often gains insights and develops interpersonal relationships that are virtually impossible to achieve through any other method" (p. 26).

\subsection{Method of Data Collection}

This exploratory study employed qualitative techniques for data collection to achieve a fuller understanding of the research phenomenon (Jupp, 2006). For this purpose, semi-structured interviews were conducted to explore EFL learners' perceptions and experiences of journal writing in the Saudi EFL context. Qualitative interview is defined as "a uniquely sensitive and powerful method for capturing the lived experiences and lived meanings of the subjects' everyday world" (Kvale, 2007, p. 11). Similarly, Scott and Usher (2006) further highlight that "the core issue for researchers who use interviews in qualitative research is to seek in-depth understandings about the experiences of individuals and groups, commonly drawing from a small sample of people, selected purposively. Such types of interviews are called semi-structured" (p. 147). This research has employed semi-structured interviews to benefit from its flexible structures that give the EFL learners freedom to express their views (Flick, 2002) as well as it allows the researchers to develop unpredicted themes and problems that emerge during interviews (Cohen et al., 2007; Mason, 2002). The questions, probes, and prompts for the purpose of semi-structured interviews were generated in the light of the reviewed literature on the topic of journal writing and our personal observation and experience of journal writing in this context.

The semi-structured interviews were conducted in the English language as the EFL learners could communicate in English and were able to share their views fluently, which helped us transcribe the interviews easily. All interviews were audio-recorded and each interview lasted for 20 to 30 minutes.

\subsection{Participants}

In this qualitative study, twenty-two female EFL learners participated whose consent was sought before the start of the study. All the learners were intermediate level students who had studied the English language for more than six years in schools and for about seven months in PYP. Prior to the start of the research, the participants were communicated the aims and objectives of the research and were given the right to withdraw at any stage of the study. Before the study was initiated, ethical approval was granted from the vice dean of the graduate studies at the ELI.

We used purposive sampling to select female leaners who had the experience of writing journals. The chosen participants were in the best position to give the most relevant information on the topic of journal writing (Patton, 2002; Cohen et al., 2007).

\subsection{Data Analysis}

The qualitative data were inductively analyzed employing interpretive phenomenological 
analysis approach (Patton, 2002; Silverman, 2011). The interview transcripts were repeatedly read through in a bid to make sense of the participants' views as Marshall and Rossman (2006) explains: "Reading, reading, and rereading through the data, once more, forces the researcher to become intimately familiar with those data" (p. 158). An initial reading of the transcripts helped us locate relevant and important information. We used an iterative and inductive approach throughout the analysis of the qualitative data. We manually coded the data that generated codes and categories. Initial coding generated 105 open codes. Later, identical codes were merged and 30 categories were created. After prolonged deliberation, 30 categories were collapsed under 5 overarching themes which were aiming to answer the three research questions. The major themes were: A) The Trend of Writing a Journal in the Saudi Context, B) The Significance of Writing a Journal in the Saudi Context, C) The Impact of Writing a Journal on EFL Learners' Writing Skills, D) The Challenge of Writing a Journal in the EFL Context, and E) The Future of Writing a Journal in the Saudi EFL Context.

\subsection{Ethical Considerations}

Prior to the research, ethical issues were considered as ethics is a vital consideration for educational research. First of all, the research proposal was shared with the vice dean of the graduate studies and her permission for conducting research on the site was sought. Afterward, the students were told the aims, benefits and expected outcomes of the proposed research. For the purpose of anonymity of the participants and the confidentiality of their views, they were given a choice to use pseudonyms which were cited in the data analysis section (Neuman, 2006).

\section{Findings}

This section of the paper presents the qualitative data in the form of students' most significant quotes which resulted as inductive analysis. Later in section 5, the findings are discussed in the light of the existing literature. The themes presented in this section are representative of the participants' views which aim to answer the three research questions.

\subsection{The Trend of Writing a Journal in the Saudi Context}

The qualitative data suggest that journal writing is not a common practice and the notion is a novel one in the Saudi EFL context. The learners express their dissatisfaction with the existing practice and consider it a concept that receives no or little attention in the Saudi context.

I do write a journal on weekly basis, but I don't think it's a popular thing with most of the Saudi students. (Participant 18)

Writing a journal is a new concept here. We were encouraged by teachers who made us believe that we wouldn't succeed without having excellent writing skills. But generally speaking, students have little interests in journal writing and teachers don't often motivate students to write journals. (Participant 4) 
The findings also indicate that students have an exam-oriented approach. They are focused on tests and grades and thus writing for pleasure has no room for EFL learners in this context.

Grades are the most important thing for us. If we don't get rewarded for our tasks, we wouldn't put extra efforts. I believe students always need grades to achieve a higher GPA; however, journal writing doesn't have this attraction for students at large. motivation. (Participant 2)

The point is whether journal writing has any tangible rewards. If yes, I will definitely do it regularly, if not, there won't be any motivation. Most of us do it for pleasure, but that too in our free time and of course not during the exam week. (Participant 6)

\subsection{The Significance of Writing a Journal in the Saudi Context}

The findings of this research consider the practice of journal writing an important aspect of foreign language learning, however, it has not been given its due importance by the management or policy makers. The learners believe that journal writing has contributed to their improved writing skill, but it is their individual effort and not a mandatory part of their language course or program.

If writing a journal becomes compulsory, it will help the students become effective writers. Unfortunately, it has not been part of the curriculum in our college. (Participant 9)

Journal writing has no importance for the top management. Although students find it an interesting activity that impacts their writing skills, leadership has not realized its role in the academic achievement of EFL learners. (Participant 2)

To me, there is a lack of opportunities for students to practice the English language outside the classroom. For this reason, I deem it an important activity in this context and would like the management to integrate it into classroom syllabus so students can benefit from it. (Participant 3)

The above quotes illustrate that the ELI curriculum places little or no emphasis on the practice of journal writing. Although, the findings do not shed light on the reasons for its absence in pedagogical practices, it is interesting to note that participants have noticed the pivotal role of journal writing in developing their English proficiency as they do not find it easy to practice the English language outside language classrooms.

\subsection{The Impact of Writing a Journal on EFL Learners' Writing Skills}

The EFL learners in this study have underscored the crucial role of journal writing in their bid to develop writing skills. They think that journal writing practice has influenced their thought processing, the organization of ideas and putting ideas on a paper with confidence. As a result of journal writing, they have become autonomous writers who can choose their topics and write about them freely. The following excerpts are specimens of what the participants at large shared. 
Freewriting has never been my hobby. Due to writing a journal I developed my interest in it and made it a regular practice. As a result, I learned how to write freely without any fear of mistakes. (Participant 8)

It was never easy to think in English. with writing journals, I can now easily think and organize ideas in English. I can write about whatever I consider important or relevant. (Participant 11)

Since there is no fear of losing marks, I can write better. (Participant 18)

The practice of writing a journal gave them a purpose and they managed to write with a goal in mind.

I write daily, so I can become a good writer. For me, writing a journal is writing for pleasure and I enjoy it. (Participant 7).

Writing a journal developed my interest in my daily diary and now I feel as I write my autobiography. No doubt, it is recording my daily activities and I try not to miss it. (Participant 5)

My writing skill has certainly improved and I feel that I will be able to write a research paper. (Participant 20)

It helps me write what I really like and I don't have any fear of failure. (Participant 13)

It's a great way of keeping a record of my life stories. There is always something interesting to share with others. (Participant 21)

The above quotes suggest that learners have the options of choosing the topics that interest them and can keep the record of their entries which they consider a good learning experience.

\subsection{The Challenge of Writing a Journal in the EFL Context}

The findings of this small-scale qualitative study show that writing a journal is not easy due to certain factors. These factors are contextual, academic and pedagogical.

It is evident from the findings that learners' lack the required knowledge of vocabulary to write in English. As writing a journal requires more effort, students often experience difficulty to write at length and express their opinions.

Writing is not easy. I think it's difficult to write on unfamiliar topics and use a variety of words. The main reason is that we do not have a lot of words to write on a complex topic. (Participant 2)

The existing course doesn't focus much on developing vocabulary that can be used to write about anything we want. The topics of journal writing can be very different from typical classroom topics and we need to increase a vocabulary range for it. (participant 10)

The data reveal the learners' awareness of their basic weakness which is probably a 
culturally specific phenomenon. The students' lack of interest in reading books and magazines is one of the reasons that affects their ability to write. Since they do not have sufficient vocabulary to express themselves, their performance in writing a journal is negatively influenced.

The Saudi students don't get enough writing practice in schools and when they come to universities, they usually lack the skills to write in English. They don't like reading as well, which also affect their vocabulary acquisition. The lack of vocabulary leads to their failure to express their views while writing on a specific topic. (Participat 16)

Another factor that has an impact on the learners' inability to write a journal is lack of time. Students have 18 hours of English course in a week along with other subjects. The burden of other courses makes it difficult for them to put in extra effort and write a journal. The participants' responses also indicate that EFL teachers lack time and resources to introduce the practice of journal writing in classrooms. Since teachers have to cover a prescribed syllabus while following a specific course outline, they cannot afford to supplement material or add to the students' work.

We do not have time for journal writing. We need to study other subjects as well and journal writing consumes a lot of time. I believe students need more time and space in order to focus on writing their personal journals. (Participant 2)

Teachers stick to the pacing guide and cannot afford experimentations. This is an obstacle to the teaching or encouraging the practice of journal writing. (Participant 12)

We don't have time for journal writing due to other subjects that we have to cover. There are too many quizzes and tests which don't allow us to spare time for such a time-consuming activity. (Participant 16)

One of the major barriers that the findings of this study brings forth is the lack of parental support or the parents' attitudes to their children's learning. Ideally, parents should keep a close check on their children's learning progress and frequently ask them to exhibit their performances. However, the findings suggest that students do not enjoy the support of their parents, teachers and management in this respect.

Our parents mostly do not know about their learners' achievements or failures at university. Parents can play a positive role if they hold their kids accountable for under performance. If parents take show interest, teachers cannot do much about learners. Writing a journal will require both parents and teachers to push students for extra efforts. (Participant 2)

Overall, the Saudi students don't get encouraged by their parents and peers to write their journals. I think lack of support from parents, teachers, and management are factors that make the process of journal writing a challenging phenomenon for Saudi EFL learners. (Participant 1)

I think if we do not have sufficient support from the teachers, writing journal is 
never an easy task. (Participant 10 )

In general, the teachers seem to know little about journal writing. They usually focus on the textbook and of course, journal writing isn't part of the textbook. (Participant 19)

The problem is that we don't get immediate feedback on our journal writing drafts and at times, I feel as there are too many mistakes in my work. Since teachers lack time to correct our work and give feedback, most of the time we consider it a futile activity. (Participant 15)

The above excerpts from the interviews make it clear that students may find it a pleasing experience if the abovementioned barriers are removed. Support from their parents and teachers can help them write their journals and improve their writing skills in a comfortable fashion.

\subsection{The Future of Writing a Journal in the Saudi EFL Context}

The findings indicate that journal writing will have to become an integral part of the students' academic endeavors in order to ensure their success as EFL learners. It may not be a popular practice in the Saudi context; however, it will gain popularity as the voices of the students have to be heard.

Writing a journal is a popular concept in other contexts. It is not a common model here but I'm sure that the universities will consider this option soon as students in other countries benefit from this practice. (Participant 13)

The findings have suggested that EFL learners can only raise their language proficiency if they develop their writing skills. The practice of journal writing will give them a chance to exploit their creative and innovative skills. The following excerpt is a specimen of what other participants think.

Our university courses require us to write up lengthy assignment in order to meet certain criteria. Journal writing can be an effective tool when we need to be good writers as we get a chance to write on various topics with no fear of being failed or marked down. If we make it a part of a course syllabus, students can benefit in long run (Participant 10).

As the concept of free writing is closely linked to the practice of journal writing, the participants' experience indicates that students gain more confidence in writing on more complex subjects.

Journal writing involves free writing and free writing may have errors, but they don't usually impact the students' grades as the drafts are not evaluated. This element enables the learners to write without thinking much about their mistakes. If teachers emphasize on free writing as part of journal writing, it can lead to developing students into very good writers. (Participant 2)

The above suggestions are important considerations in the light of the participants' views 
about achieving the Vision 2030. The participants consider 'journal writing' a ladder to success in their academic and professional careers.

The perception that Arab learners in general and Saudi learners, in particular, are not good writers, must go away. To achieve the Vision 2030, we must realize the fact that writing is a key skill and we cannot excel as a nation if we lack the ability to write well in a global language such as English. Of course, writing journals is one of the most effective methods for developing our writing skills. (Participant 5)

The Saudi government has invested a lot in this PYP and I don't know if it has really made any difference to the EFL learners' overall language proficiency. Whatever the case may be, I strongly believe that there should be more focus on the students' writing skills. Activities like free writing in the classroom, writing a daily diary and writing a journal can leave a strong impact on the students' understanding of writing mechanics. I think sooner or later, there will be a need for such activities as we as learners have no future without being able to write well. (Participant 2)

The above quotes illustrate the futuristic views of the Saudi EFL learners who knows the pivotal role journal writing can play in the attainment of vision 2030.

\section{Discussion}

In this section of the paper, the qualitative findings of this small-scale study have been discussed in the light of the existing literature. The findings have answered the three overarching research questions which are:

1. To what extent do EFL learners consider journal writing an important tool for improving their writing skills?

2. What are the EFL learners' perceptions of their experience of journal writing in an EFL classroom?

3. What are the factors that hinder the process of journal writing in the Saudi EFL context?

The perceptions and experiences of Saudi EFL learners reveal that academic achievement may not be possible without improved writing skills and writing a journal is an important component of EFL learning. The claim is similar to what Chanderasegaran (2002) believes that writing outside the classroom is also a useful tool for improving the writing skill.

The students' perceptions show that the activity of writing a journal yields a number of benefits. For instance, they can organize their thoughts, come up with new and creative ideas and can refer to their writings or journal entries anytime. The views of the learners are in line with Mllynarczyk's (1998), Spaventa's (2000) and Ngoh's (2002) findings who also found the creative aspect of free writing that is the outcome of writing a journal. This also indicates the fact that EFL students were able to develop their analytical approach (Simpson, 1986) that 
helped them organize their ideas and record them in chronological order.

More importantly, as Hamp and Heasley (2006) consider it an opportunity to write freely on daily basis with no fear of failures, findings of this study also suggest that students often feel independent while writing a journal and there is no pressure of making mistakes that can hinder their progress (Spaventa, 2000; Mllynarczyk, 1998). In the context of language teaching and learning, it is important to write about topics that are relevant to the learners' interests. Students in this study seem to be aware of this 'active learning technique' (Chickering \& Gamson, 1987). Moreover, the findings suggest that the freedom of choosing a topic, writing about their feelings in a comfortable environment and personalizing it are the factors that give them ownership of the journal entries. This is exactly what Ediger (2001), Hettich (1976), Good (1999), Cisero (2006) and Heron (2003) concluded about writing a journal in a foreign language learning context.

More on the benefits of journal writings, the participants' enthusiasm shows their active involvement in their writing of journals. It also confirms the fact that writing is a reflective process which motivates writers to think aloud, reflect on their expressions and discuss the content with peers or teachers (Surbeck, 1994). Owing to the Saudi EFL students' active participation discussed by the participants, the whole practice becomes a meaningful one and they can connect their ideas and journal entries to the real world as described by Apps (1991) and Haglund (1998).

The findings are indicative of the fact that intermediate level female EFL students consider journal writing an interesting and enjoyable experience. However, while talking about the challenges, they mentioned lack of support from the management, parents and teachers. A bit of contradiction was observed in the findings as the participants have the experience of writing journals, and their only source of encouragement was their few teachers who encouraged them to actively follow the practice of writing a journal, which is similar to White and Arndt's (1991) suggestions.

The participants have been writing journals; however, they point out lack of support from their teachers, management and parents which cast doubts on this practice in the Saudi context. Dodson (2001) considers teachers as a resource person and he or she should have the materials, tools, and encouragement to enable students to write their journals. Students in this study have also demanded the proactive roles of EFL teachers in this respect. Despite the lack of support, the findings of this research corroborate with the results presented by Pierson (2004) and Ediger (2001). It appears as the EFL learners are aware of the benefits as well as the goals of journal writing as stated by Pierson (2004) and Ediger (2001). Their awareness also indicates their level of motivation which is deemed a driving and instrumental force for learning a foreign language.

The qualitative findings have highlighted the crucial role journal writing plays in the development of writing skills of EFL learners; however, it has not been a commonly-used practice in Saudi Arabian universities. Bearing its advantages in mind, it should be considered a mandatory part of the PYP which will contribute to the learning outcomes of the students. As the concept is novel and there is a serious dearth of research on this topic, this 
study has introduced the notion of journal writing and underscored its potential benefits for language learners and teachers in the Saudi EFL context. Despite its numerous advantages for learners and teachers, journal writing seems to be a novel concept in the Saudi EFL context.

\section{Limitations of the Study}

This small-scale study has certain limitations. It was conducted on the female campus of the ELI with twenty-two female students and the perceptions of male students were not included due to social restrictions. The experiences of male EFL learners might have given interesting insights into the research phenomenon. Moreover, this study utilized a qualitative data collection tool; however, it used only semi-structured interviews for this purpose. Other tools, such as observations, focus groups or surveys could have given more varied and enriched perspectives of journal writing in the Saudi context. Moreover, mixing of data collection methods might have yielded more valid and trustworthy data.

\section{Conclusion}

This small-scale qualitative study has attempted to explore the Saudi EFL learners' perceptions and experiences about their journal writing practice. It is considered an activity that usually takes place outside the classroom as part of free writing practice. In the orbit of interpretive paradigm, the utilization of qualitative techniques has helped us understand the perceptions of EFL students which indicate the significance of journal writings in this context. The study has brought certain challenges into the light, such as lack of support for students, time constraints and little or no feedback from the teachers on their journal entries. Despite challenges, the EFL students seem to be keen on writing journals and have underscored its role in the development of their writing skills. The findings have also highlighted the fact that writing a journal has not been a popular concept in Saudi Arabia; however, it should be given its due attention if the Saudi educational institutions have to achieve the objectives of vision 2030. The participants seem to be aware of its significance in relation to their future academic achievement both in the individual as well as collective capacity. In terms of future goals, the findings strongly make a point that to meet the challenges of $21^{\text {st }}$ century and realizing the importance of English as a global language, the educational institutions around the Kingdom should integrate journal writing into EFL curriculums. This approach will enable the teachers and students to develop rapport and work together in a conducive learning milieu in their collective bid to attain teaching and learning outcomes. More research employing multiple methods while including EFL learners' and teachers' views and their experiences will further help the policymakers to consider its pros and cons and make the practice of journal writing an effective teaching and learning tool in the Saudi EFL context. 


\section{Macrothink}

\section{References}

Apps, J. W. (1991). Mastering the teaching of adults. Malabar, FL. Krieger Publishing Company. https://eric.ed.gov/?id=ED362671

Borg, W. R., \& Gall, M. D. (1983). Educational research (4th ed.). New York: Longman. https://trove.nla.gov.au/work/11697416

Byrne, D. (1991). Teaching writing skills. Hong Kong: Longman. Retrieved from https://www.academia.edu/5542884/49860749-Byrne-Teaching-Writing-Skills

Chanderasegaran, A. (2002). Intervening to help in the writing process. RELC Portfolio Series 7.

Retrieved

from

https://openlibrary.org/books/OL19393960M/Intervening_to_help_in_the_writing_process

Chickering, A.W., \& Gamson, Z.F. (1987). Seven principles for good practice in undergraduate education. AAHH Bulletin. Retrieved from http://www.lonestar.edu/multimedia/SevenPrinciples.pdf

Cisero, C. A. (2006). Does reflective journal writing improve course performance?. College Teaching, 54(2), 231+. https://doi.org/10.3200/CTCH.54.2.231-236

Cohen, L., Manion, L., \& Morrison, K. (2007). Research methods in education (6th ed.). London: Routledge. Retrieved from https://islmblogblog.files.wordpress.com/2016/05/rme-edu-helpline-blogspot-com.pdf

Dotson, J. M. (2001). Cooperative learning structures can increase student achievement. Kagan online mag. Retrieved from https://www.kaganonline.com/free_articles/research_and_rationale/increase_achievement.ph pazine, 25.

Ediger, M. (2001). The student, journal writing, and the social studies. College StudentJournal, 35(4), 560-565.

Good, J. M., \& Whang, P. A. (1999). Making meaning in educational psychology with student response journals. Paper presented at the annual meeting of the American Educational Research Association, Montreal, Canada.

Flick, U. (2002). An introduction to qualitative research. London: Sage Publication. Retrieved from https://mycourses.aalto.fi/pluginfile.php/551900/mod_resource/content/0/Uwe_Flick_An_Int roduction_to_Qualitative_Research.pdf

Wilson P., \& Glazier, T. F. (1994). The least you should know about English writing skills. USA: Harcourt Brace College Publishers. Retrieved from https://www.cengage.com/c/the-least-you-should-know-about-english-writing-skills-13e-wils on/

Haglund, E. (1998). What's right with education? Erin Gruwell's reconnecting the disconnected.Education, 119(2), 300. 
Hamp-Lyons, L., \& Heasley, B. (2006). Study writing: A course in written English for academic purposes. Cambridge University Press. Retrieved from https://www.amazon.com/Study-Writing-English-Academic-Purposes/dp/0521534968

Hashemi, Z., \& Amerian, M. (2017). The impact of journal writing on the correct use of grammar among EFL students of Ragsanjan Vali-e-Asr university. The English Teacher, 12. Retrieved from https://pdfs.semanticscholar.org/46b5/f9d0607460349c4d46f04f3e44eeee803b72.pdf

Hedge, T. (1991). Writing. Hong Kong: Oxford University Press. Retrieved from https://global.oup.com/academic/product/writing-9780194421904?lang=en\&cc=es

Hettich, P. (1976). The journal: An autobiographical approach to learning. The teaching of Psychology, 3(1), 60-63. https://doi.org/10.1207/s15328023top0302_3

Jupp, V. (2006). The sage dictionary of social research methods. London: SAGE. https://doi.org/10.4135/9780857020116

Kvale, S. (2007). Doing interviews. London: Sage. https://doi.org/10.4135/9781849208963

Marshall, C., \& Rossman, G. B. (1999). The "what" of the study: Building the conceptual framework. Designing qualitative research, 3, 21-54.

Marshall, C., \& Rossman, G. (2006). The how of the study: Building the research design. Designing qualitative research, 55-101. Retrieved from https://escholarship.org/uc/item/3m25g8j8

Mason, J. (2002). Qualitative interviewing: Asking, listening and interpreting. In T. May (ed.), Qualitative Research in Action (pp. 225-240). London: Sage Publication. Retrieved from http://trove.nla.gov.au/work/32819059?q=Qualitative+Research+in+Action\&c=book\&sort=h oldings+desc\&_=1361310623515\&versionId $=46528046$

Mlynarczyk, R. W. (1998). Conversations of the mind: The uses of journal writing for second language learners. Mahwah, NJ. Lawrence Erlbaum Associates. https://doi.org/10.4324/9781315045092

Neuman, W. L. (2006). Social research methods: Qualitative and quantitative approaches. Toronto: Pearson. Retrieved from http://letrunghieutvu.yolasite.com/resources/w-lawrence-neuman-social-research-methods_-q ualitative-and-quantitative-approaches-pearson-education-limited-2013.pdf

Ngoh, T. J. (2002). From Journals to Weekly Papers. Guidelines, 24.

Nunan, D. (1999). Second language teaching \& learning. Heinle \& Heinle Publishers, 7625 Empire Dr., Florence, KY 41042-2978. Retrieved from https://eric.ed.gov/?id=ED441344

Patton, M. Q. (2002). Qualitative research and evaluation methods. Thousand Oaks: Sage. Retrieved from https://us.sagepub.com/en-us/nam/qualitative-research-evaluation-methods/book232962 
Pierson, D. J. (2004). The top 10 reasons why manuscripts are not accepted for publication. Respiratory care, 49(10), 1246-1252. Retrieved from https://www.ncbi.nlm.nih.gov/pubmed/15447812

Shamim, F. (1996). In and out of the action zone: Location as a feature of interaction in ichpilarge ESL classes in Pakistan. In K. M. Bailey \& D. Nunan (Eds.), Voices from the Language Classroom (pp. 123-144). Cambridge: Cambridge University Press.

Silverman, D. (2011). Retrieved from https://ecommons.aku.edu/book_chapters/105/

Simpson, M. L. (1986). PORPE: A writing strategy for studying and learning in the content areas. Journal of Reading, 29(5), 407-414. Retrieved from https://eric.ed.gov/?id=EJ329407

Spaventa, S. (2000). Essay Writing. Cambridge: Cambridge University Press.

Tho, L.N.M. (2000). A Survey of Writing Problems of USSH First-Year Students of English. Ho Chi Minh City.

Surbeck, E. (1994). Journal writing with preservice teachers. Childhood Education, 70(4), 232+. Retrieved from https://www.questia.com/library/journal/1G1-15443847/journal-writing-with-preservice-teac hers

Weir, C. J. (1990). Communicative language teaching. GB: Prentice Hall International. Retrieved from http://free.filesearch.club/?q=communicative+language+testing+weir+pdf

\section{Copyright Disclaimer}

Copyright for this article is retained by the author(s), with first publication rights granted to the journal.

This is an open-access article distributed under the terms and conditions of the Creative Commons Attribution license (http://creativecommons.org/licenses/by/3.0/). 